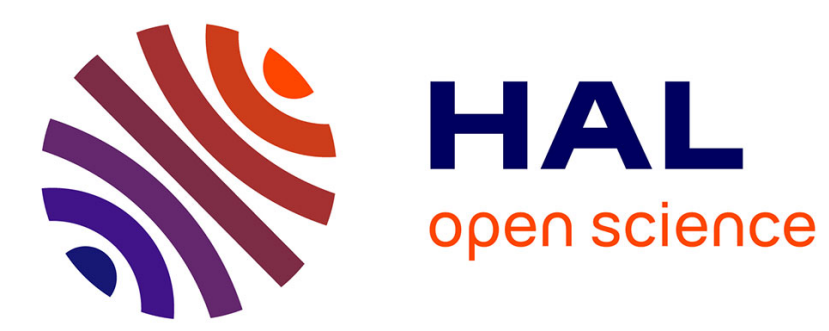

\title{
Tone and inflection: An introduction
}

Enrique L. Palancar, Jean-Léo Léonard

\section{To cite this version:}

Enrique L. Palancar, Jean-Léo Léonard. Tone and inflection: An introduction. 2015. hal-01099327

\section{HAL Id: hal-01099327 \\ https://hal.science/hal-01099327}

Preprint submitted on 2 Jan 2015

HAL is a multi-disciplinary open access archive for the deposit and dissemination of scientific research documents, whether they are published or not. The documents may come from teaching and research institutions in France or abroad, or from public or private research centers.
L'archive ouverte pluridisciplinaire HAL, est destinée au dépôt et à la diffusion de documents scientifiques de niveau recherche, publiés ou non, émanant des établissements d'enseignement et de recherche français ou étrangers, des laboratoires publics ou privés. 


\title{
Tone and inflection: An introduction
}

\author{
Enrique L. Palancar \\ Jean-Léo Léonard
}

Accepted in Enrique L. Palancar \& Jean-Léo Léonard (eds.),

Tone and Inflection: New facts under new perspectives. Submitted to DeGruyter, Oct. 2014

\section{Introduction.}

Tone is about melody and meaning, inflection is about grammar and this book is about a bit of both. The different papers in this book study possible and sometimes very complex ways in which the melodies of a given language engage in the expression of grammatical meaning. In this light, the volume aims to broaden our understanding of the role of tone in the making of grammar. We believe this is important because it challenges a widespread conception of tone as being a lexical phenomenon only. This conception flows from the expectation that any typical tone language should be like Mandarin Chinese or Vietnamese, but these are languages with little or no inflectional morphology. The contributions in this volume challenge this view by showing that there is more to tone than meets the eye.

We know well that tone can just be about the lexicon, and it often is. We know a little less when it goes yonder into the morphology, but it often also does. In an ideal world, if one were to view tones as just another part of the phonological system, the role of tone in inflection would come as no surprise to anybody. One could argue that just as segments -alone or in combination- are recruited by the inflectional morphology in the form of affixes or clitics for the realization of inflectional categories, it is expected that the units of the tonal phonology should do the same, at least in principle, providing of course the language in question has inflectional morphology. In reality things are more complex because even when one may believe that whatever segmental phonology does, tonal phonology can do better, or at least in more interesting ways - this is the belief we adopt here inspired by Hyman (this volume) - it still remains true that tone abides by its own special rules, specific to the nature of its suprasegmental modality. Because of this, its role and status remains to date a matter of interest for phonology in its interface with morphology and syntax.

A few examples may perhaps suffice to show this important point. From a morphosyntactic perspective concerned about the mapping between linguistic form and grammatical meaning, the status of tone could appear unclear: (i) should tones be viewed as discrete auto-segments landed on segments, that is, as inflectional exponents in their own right? or (ii) should tones be regarded as a lexical property of an inflected stem and thus be seen as information provided by the lexical phonology? The best answer would perhaps be one based on language-specific grounds. In this introductory chapter, we briefly revise the different types of tone behaviors found in different inflectional systems.

\subsection{The Mixtec case: Tone as a morphosyntactic exponent.}

For the first question, consider the role of tone in the verbal inflection of Yoloxóchitl Mixtec, a language of Mexico of the Oto-Manguean macro-phylum. Yoloxóchitl Mixtec has nine basic tones involved in lexical contrasts (cf. Vietnamese has six according to the common view): four level tones (written as superscript numbers from $/ 1 /$ for the low tone through $/ 4 /$ for the high tone); three rising tones (/13/, /14/, /24/) and two falling tones $(/ 32 /, / 42 /)$ (DiCanio et al. 2012). Out of these nine tones, four are fully exploited in the inflection. The examples in table 1 illustrate the forms for the irrealis (IRR), negative irrealis (NEG.IRR) and 
completive (CPL) of a representative set of verbs from Yoloxóchitl Mixtec. For this language, the tones in the irrealis can be taken as basic; that is, as provided by the lexicon (see Palancar et al., this volume).

Table 1. Tone and verbal inflection in Yoloxóchitl Mixtec.

\begin{tabular}{lllll}
\hline IRR & NEG. IRR & $\mathrm{CPL}$ & & \\
\hline $\mathrm{nu}^{3} \mathrm{mi}^{3}$ & $\mathrm{nu}^{14} \mathrm{mi}^{3}$ & $\mathrm{nu}^{13} \mathrm{mi}^{3}$ & 'hug' & (tr) \\
$\mathrm{ku}^{3} \mathrm{u}^{3}$ & $\mathrm{ku}^{14} \mathrm{u}^{3}$ & $\mathrm{ku}^{13} \mathrm{u}^{3}$ & 'happen' & (intr) \\
$\mathrm{nda}^{3} \mathrm{kin}^{2}$ & $\mathrm{nda}^{14} \mathrm{kin}^{2}$ & $\mathrm{nda}^{13} \mathrm{kin}^{2}$ & 'sharpen' & (tr) \\
$\mathrm{ku}^{3} \mathrm{ya}^{3} \mathrm{tin}^{3}$ & $\mathrm{ku}^{14} \mathrm{ya}^{3} \mathrm{tin}^{3}$ & $\mathrm{ku}^{13} \mathrm{ya}^{3} \mathrm{tin}^{3}$ & 'get closer' & (intr) \\
$\mathrm{ndu}^{3} \mathrm{to}^{3} \mathrm{ni}^{3}$ & $\mathrm{ndu}^{14} \mathrm{to}^{3} \mathrm{ni}^{3}$ & $\mathrm{ndu}^{13} \mathrm{to}^{3} \mathrm{ni}^{3}$ & 'open eyes' & (intr) \\
$\mathrm{nda}^{3} \mathrm{xiP}^{3} \mathrm{i}^{4}$ & $\mathrm{nda}^{14} \mathrm{xi}^{3} \mathrm{i}^{4}$ & $\mathrm{nda}^{13} \mathrm{xi}^{3} \mathrm{i}^{4}$ & 'open' & (tr) \\
$\mathrm{cha}^{3} \mathrm{ka}^{3} \mathrm{ndu}^{4} \mathrm{u}^{4}$ & $\mathrm{cha}^{14} \mathrm{ka}^{3} \mathrm{ndu}^{4} \mathrm{u}^{4}$ & $\mathrm{cha}^{13} \mathrm{ka}^{3} \mathrm{ndu}^{4} \mathrm{u}^{4}$ & 'lay down' & (tr) \\
etc. & & & & \\
\hline
\end{tabular}

In table 1 , we have verbs with different melodies in their base form (i.e. the irrealis): $/ 3-2 /$, /3$3 /, / 3-3-3 /, / 3-3-4 /$ and $/ 3-3-4-4 /$. If this form is compared with the tonal melodies present in the other two forms, we see that the only element that changes is the tone on the first mora. The melodies of the base forms all have in common a tone $/ 3 /$ on the first mora. We can further see that verbs of this type (i.e. those having a /3/ on the first mora) will also have /14/ for the negative irrealis and $/ 13 /$ for the completive on their respective first morae. The mapping of form (i.e., a specific tone value) and grammatical meaning (i.e., a specific inflectional value) is constant and exceptionless. This remarkable systematicity leaves us with an inflectional system operating with flawless morphosyntactic rules that involve tone. In such a system, tone could be said to work as a regular suprasegmental affix: the affix being suppletive for the negative irrealis (i.e. /14/ replaces /3/ on the first mora of the stem), or additive for the completive (i.e. $/ 1 /$ is inserted before the lexical $/ 3 /$ on the first mora of the stem producing a raising tone $/ 13 /$ which is also found as a unit in other lexical items, namely nouns, e.g. $\operatorname{ta}^{l} a^{3}$ 'man').

This regularity makes of Yoloxóchitl Mixtec a dream language for syntactic approaches to inflection that are not interested in the messy bits of the morphology. However, "tone will be tone", and because of this we often find it fully involved in the making of those messy bits. For this purpose, consider first Tlatepuzco Chinantec, another Oto-Manguean language of Mexico spoken in the locality of Palantla, at $300 \mathrm{~km}$ from Yoloxóchitl as the crow flies, but impressionistically as distant a system to Mixtec as Hindi is to Gaelic.

\subsection{The Chinantec case: Tonal classes.}

Tlatepuzco Chinantec has six tones involved in lexical contrasts (cf. Mandarin Chinese has only four): three level tones and two rising contours (low-mid /12/ and low-high /31/). Out of these six tones, five are involved in verbal inflection and in very intricate ways. For this consider the following. Verbs in Chinantec inflect for TAM by means of prefixes (including zero prefixes or bare stems). These prefixes associate in turn to stems inflected by tone for aspect/mood, e.g. the past prefix $c a^{l}$ - and the hodiernal past prefix $n a^{2}$ - need to be affixed to the completive stem and not other. The same tones in the stems also indicate distinctions in the person of the subject. The relevant persons here are 1st person singular and plural, 2nd person and 3rd person (see for example Merrifield 1968, Pace 1990, Foris 2000, etc.). In table 
2 we give the tones of the three different stems (completive (CPL), incompletive (INCPL), and irrealis (IRR)) for five different verbs from Merrifield and Anderson (2007). 
Table 2. Tone and verbal inflection in Tlatepuzco Chinantec.

\begin{tabular}{|c|c|c|c|c|c|c|c|c|c|c|}
\hline \multirow{7}{*}{ CPL } & \multirow{7}{*}{$\begin{array}{l}\text { a. } \\
\text { b. } \\
\text { c. } \\
\text { d. } \\
\text { e. } \\
\text { f. }\end{array}$} & \multirow{7}{*}{$\begin{array}{l}\text { 'bend' } \\
\text { 'gnaw' } \\
\text { 'bring' } \\
\text { 'call' } \\
\text { 'cut' } \\
\text { 'scare' }\end{array}$} & \multicolumn{2}{|l|}{$1 \mathrm{SG}$} & \multicolumn{2}{|c|}{$1 \mathrm{PL}$} & \multicolumn{2}{|l|}{2} & \multicolumn{2}{|l|}{3} \\
\hline & & & húP ${ }^{1}$ & 1 & hú2 ${ }^{13}$ & 13 & hú21 & 1 & hú? ${ }^{2}$ & 2 \\
\hline & & & tsǿ? ${ }^{1}$ & 1 & tsǿ:13 & 13 & tsǿ? ${ }^{1}$ & 1 & tsǿ? ${ }^{1}$ & 1 \\
\hline & & & quián ${ }^{1}$ & 1 & quián ${ }^{13}$ & 13 & quián ${ }^{12}$ & 12 & quián ${ }^{2}$ & 2 \\
\hline & & & tǿ? ${ }^{1}$ & 1 & tǿ ${ }^{13}$ & 13 & tǿ? ${ }^{12}$ & 12 & tǿ $P^{1}$ & 1 \\
\hline & & & $\operatorname{tiu}^{1}$ & 1 & tiu $^{3}$ & 3 & $\mathrm{tiu}^{32}$ & 32 & tiu $^{1}$ & 1 \\
\hline & & & Pán ${ }^{2}$ & 2 & Pán ${ }^{13}$ & 13 & Pán ${ }^{1}$ & 1 & Pán ${ }^{2}$ & 2 \\
\hline \multirow[t]{6}{*}{ INCPL } & \multirow{6}{*}{$\begin{array}{l}\text { a. } \\
\text { b. } \\
\text { c. } \\
\text { d. } \\
\text { e. } \\
\text { f. }\end{array}$} & \multirow{6}{*}{$\begin{array}{l}\text { 'bend' } \\
\text { 'gnaw' } \\
\text { 'bring' } \\
\text { 'call' } \\
\text { 'cut' } \\
\text { 'scare' }\end{array}$} & hú? ${ }^{12}$ & 12 & hú? ${ }^{12}$ & 12 & hú? ${ }^{12}$ & 12 & hú? ${ }^{2}$ & 2 \\
\hline & & & tsǿ? ${ }^{12}$ & 12 & tsǿ: & 12 & tsǿ? ${ }^{12}$ & 12 & tsǿ? 12 & 12 \\
\hline & & & quián ${ }^{12}$ & 12 & quián ${ }^{12}$ & 12 & quián ${ }^{12}$ & 12 & quián ${ }^{2}$ & 2 \\
\hline & & & tǿ? ${ }^{12}$ & 12 & tǿ ${ }^{12}$ & 12 & tǿ? ${ }^{12}$ & 12 & tǿ $?^{2}$ & 2 \\
\hline & & & tiu $^{12}$ & 12 & tiu $^{2}$ & 2 & tiu $^{2}$ & 2 & tiu $^{12}$ & 12 \\
\hline & & & ?án² & 2 & Pán ${ }^{12}$ & 12 & Pán & 2 & Pán ${ }^{2}$ & 2 \\
\hline \multirow[t]{6}{*}{ IRR } & \multirow{6}{*}{$\begin{array}{l}\text { a. } \\
\text { b. } \\
\text { c. } \\
\text { d. } \\
\text { e. } \\
\text { f. }\end{array}$} & \multirow{6}{*}{$\begin{array}{l}\text { 'bend' } \\
\text { 'gnaw' } \\
\text { 'bring' } \\
\text { 'call' } \\
\text { 'cut' } \\
\text { 'scare' }\end{array}$} & hú? ${ }^{13}$ & 13 & hú? ${ }^{13}$ & 13 & hú? 13 & 13 & hú? ${ }^{2}$ & 2 \\
\hline & & & tsǿ: ${ }^{13}$ & 13 & tsǿ? ${ }^{13}$ & 13 & tsǿ? ${ }^{13}$ & 13 & tsǿ́ ${ }^{1}$ & 1 \\
\hline & & & quián & 13 & quián ${ }^{13}$ & 13 & quián ${ }^{13}$ & 13 & quián ${ }^{2}$ & 2 \\
\hline & & & tǿ? ${ }^{13}$ & 13 & tǿ ${ }^{13}$ & 13 & tǿ? ${ }^{13}$ & 13 & tǿ $?^{2}$ & 2 \\
\hline & & & $\operatorname{tiu}^{13}$ & 13 & $\operatorname{tiu}^{3}$ & 3 & tiú $^{3}$ & 3 & tiu $^{1}$ & 1 \\
\hline & & & Pán ${ }^{3}$ & 3 & Pán ${ }^{13}$ & 13 & Pán ${ }^{3}$ & 3 & Pán ${ }^{2}$ & 2 \\
\hline
\end{tabular}

A glance at the distribution of tones in the inflected forms in table 2 may suffice to show that tone in Tlatepuzco Chinantec verbal inflection does not work in the same predictable ways it does in Yoloxóchitl Mixtec. This is because for Chinantec there is no evident consistent mapping between form and meaning. For example, looking at the encoding of 1 st person singular in the first column, one could preliminary conclude that tone $/ 1 /, / 12$ / and $/ 13 /$ serve the function of encoding 1SG.CPL, 1SG.INCPL, and 1SG.IRR, respectively (except for the verb in (f) which would be treated as an exception to this rule). But to complete this picture, one would also have to account for the many other cases where exactly the same tones are found in other cells of the paradigm to encode other, very different grammatical information.

The tonal inflection of Chinantec provides further challenges for a theory of tone because contrary to Mixtec, in Chinantec languages identifying a form of a verb that serves as a lexical base from which the tone values of other forms can be deducted is, in our humble opinion, a futile task (for a similar argument stated differently, see Finkel and Stump, 2009). However, following Baerman and Palancar (forthcoming) we would still claim that beyond the apparent chaos there still is some structure to the system, and qui quaerit invenit...

In this regard, Baerman and Palancar (forthcoming) propose that one way to start finding this structure is to first isolate 3rd person forms as being independent from other person forms for paradigmatic purposes. If we then concentrate on the forms involving other persons, we may see some patterns emerging. For example, one possible analysis of the data in table 2 is that the verbs in (a-d) appear to abide by the same pattern: incompletive is marked by $/ 12 /$ and irrealis by $/ 13 /$ without person distinctions. But the verbs then fall into two inflectional classes attending to how they mark the completive, all encode 1 st person singular and plural by $/ 1 /$ and $/ 13 /$, respectively, whereas for the second person (a-b) use $/ 1 /$ while (c-d) use $/ 2 /$. Verbs in (e) and (f) would have to be accounted for as being deviant or 
irregular. All such verbs would then have to be further analyzed as belonging to other independent classes attending to the ways they structure the expression of the 3rd person. In reality, things become more complex when we move from a handful of verbs to hundreds for a typical Chinantecan language can be said to have more than 70 such classes (see Palancar, in press), but the data in table 2 are sufficient to illustrate how tone can also be involved in the making of a very different type of inflectional system from the one we observed in Mixtec. For Chinantec, the autosegmental view of tone does not work as neatly as one would wish, and perhaps a view taking tone as a lexical property of an inflected stem is more convenient to account for such a system, where the verbal paradigm of a verb would have to be seen as composed of stem alternation patterns. To fill the content of the cells of such patterns, one would have to learn what goes where.

\subsection{The Otomi case: Tones as phonological features of grammatical markers.}

The Chinantec case brings us to the close relation of tone to the lexicon. In fact, in many tone languages with relatively complex inflectional morphology, tone can still remain associated to the lexicon as a phonological property of inflectional affixes and clitics just as it may be associated to other lexical words. For example, in Otomi, another Oto-Manguean language family distantly related to either Chinantec or Mixtec, tone does not generally play a significant role in the making of inflection, but becomes a useful mechanism to keep grammatical markers apart, which would otherwise be homophonous. This is illustrated in (1) from the Northern Otomi spoken in San Ildefonso Tultepec in the state of Querétaro, Mexico. Here the tonal contrast high $v s$. low that serves to create minimal pairs for lexical words (e.g. 'bóts'e (H) 'religious offering' vs. 'bọts'e (L) 'basket, ribcage'; dó'yo (H) 'bone' $v s . d \grave{o} y o(\mathrm{~L})$ 'hotplate to heat tortillas', etc.) is exploited in inflectional clitics.

(1)
a. dá=tsòt'e
1. $\mathrm{CPL}=$ arrive.there
'I arrived there.'

b. gíl=tsòt'e

2.INCPL $=$ arrive. there

'You arrive there.'
Tone /L/

$\mathrm{d} \mathbf{a}=$ zò̀t'e

3. $\mathrm{IRR}=\mathrm{SS} /$ arrive there

'S/he'll arrive there.'

gi=tsồt'e

2.IRR=arrive.there

'You'll arrive there.'

The Otomi case is very common across languages, and it is a natural source for inflectional tone. In this respect, Palancar et al. (this volume) and Feist and Palancar (this volume) show instances in Mixtecan languages where the tone associated to a particular affix is disassociated from its lexical anchorage and is assigned the grammatical role of the prefix it was linked to. But see also Fedden (this volume) for a very interesting case study of how a particular tone value in Mian, a Papuan language with a rich tonal system, serves an inflectional function in a very restricted context.

Even in systems like Otomi, tones can do other things. For example a floating high tone encodes 3rd person possessor with no exceptions, that is, with the same morphosyntactic systematicity as the inflectional tones of Yoloxóchitl Mixtec. This high tone lands on the mora immediately preceding the possessed noun, may it be a determiner (2a) or a preposition in $(2 b)$. 
(2)

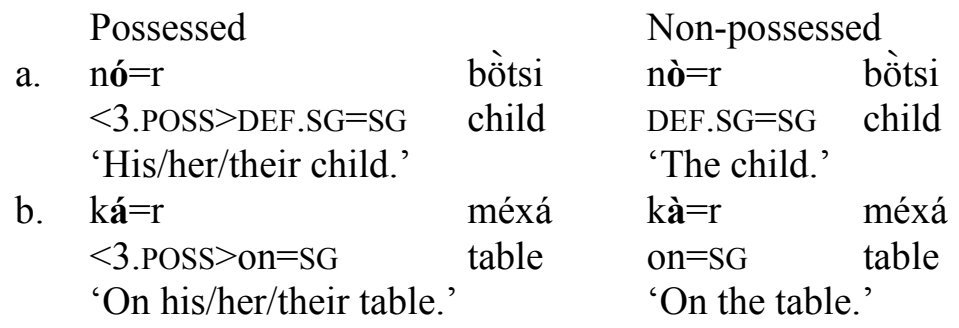

More recently, Hernández-Green (in preparation) has also observed that in the verbal inflection of Acazulco Otomi, a conservative Otomi language with more complex inflection than San Ildefonso Otomi, roots may change tone under very specific circumstances. For example, Acazulco Otomi verbs fall into four different conjugation classes. Only the verbs of the so-called 'Class I' receive a low tone for the completive of 2 nd person, the rest of the cells in the paradigm of such verbs, just like the entire paradigm of the verbs of other classes, are insensitive to this inflectional rule. This is illustrated in (3) by comparing the tone of the stems of two verbs of different classes.

\begin{tabular}{|c|c|c|}
\hline $1^{\text {st }}$ & $\begin{array}{l}\text { Class I } \\
\text { dí }=\text { ts } \breve{\mathbf{i}} \\
\text { 1.CPL }=\text { SS/eat }[3 \mathrm{OBJ}] \\
\text { 'I ate it.' }\end{array}$ & $\begin{array}{l}\text { Class III } \\
\text { dí=khă } \\
\text { 1.CPL=make[3OBJ] } \\
\text { 'I made it.' }\end{array}$ \\
\hline $2^{\text {nd }}$ & $\begin{array}{l}\text { gí=tsì } \\
\text { 3.CPL=SS/eat[3OBJ] } \\
\text { 'You ate it.' }\end{array}$ & $\begin{array}{l}\text { gíl=khă } \\
\text { 2.CPL=make[3OBJ] } \\
\text { 'You made it.' }\end{array}$ \\
\hline $3^{\text {nd }}$ & $\begin{array}{l}\text { bì }=\mathrm{z} \breve{\mathbf{~}} \\
\text { 3.CPL=SS/eat[3OBJ] } \\
\text { 'S/he ate it.' }\end{array}$ & $\begin{array}{l}\text { bì=khă } \\
\text { 3.CPL=make[3OBJ] } \\
\text { 'S/he made it.' }\end{array}$ \\
\hline
\end{tabular}

The use of tone in circumstances like in (2) is an example of a type of system where tone only operates at a specific context in the grammar. But despite its being restricted to a set of verbs (i.e. not the entire lexicon) and thus keeping a lexical connection, the use of low tone for the 2nd person completive in Acazulco Otomi still reflects a coherent mapping of one form (i.e. the suppletive low tone) to specific bundle of morphosyntactic values (i.e. 2nd person and completive aspect).

In other systems, tones may also operate in conditioned environments, but in contrast to the Acazulco Otomi case in (3) they cannot be ascribed any particular function; their distribution being purely morphological in character (Aronoff 1993). This brings us to situations where the role of tone can be better understood if seen as engaged in the building of stems in paradigms rather than in the expression of morphosyntactic features per se. When it does, it has a morphological function that resembles the role of other suprasegmental features such as stress in more familiar Indo-European languages like Latin, Greek or Russian. Inflectional systems of this type can be very complex. Two particularly illustrative examples of this type are found in Atlantic-Congo languages, Kabiyè and Tswana, and we will treat them briefly here. 


\subsection{The Kabiyè and Tswana case: Tones and the making of stems in paradigms.}

Kabiyè is a Gur language of Togo that belongs to the North-Volta Congo subgroup of the Volta-Congo branch of Atlantic-Congo. Kabiyè has a rich array of inflectional categories, to illustrate the system we only concentrate here on five basic forms: imperfective present (IMPF.PRS), aorist (AOR), imperative (IMPER), infinitive (INF), imperfective past (IMPF.PST) and perfective past (PST). For our analysis, we rely on the excellent data in Roberts (2013), who divides a sample of 800 verbs into 23 different paradigms attending to other aspects of inflection, but not tone. ${ }^{1}$ Here we are interested in two questions: (i) about the form: how can we predict the tonal shape of a stem of a given verb when that verb is inflected?; and (ii) about the function: what is the relation of tone to function? Let us address the first question.

The study of inflectional morphology is a quest for grammatical structure and analyses are just possible paths to find it. The standard procedure with tone is to take a given form as base, whose tone is considered lexical (i.e. stable and memorized), from which other forms are derived if possibly through morphophonological rules. Kabiyè is a good example for this. In order words, tone allomorphy can be predicted if one finds the key to the system to make correct generalizations.

In this regard, Kabiyè has two tones: low (not represented) and high (marked by an acute accent). The exemplar verbs for each one of Roberts' paradigms are given in table 3 together with an indication of their frequency in Roberts' sample. The forms in the table can contrast in having stems with high tone and low tone. Shading applies to the areas where we find low tone stems.

Table 3. Tone and verbal inflection in Kabiyè.

\begin{tabular}{|c|c|c|c|c|c|c|c|c|c|}
\hline & IMPF.PRS & AOR & IMPER & INF & IMPF.PST & PST & & \# & Mod \\
\hline a. & -ház-1r & -ház-1 & haz-1 & haz-v́v & -haz-aŕ & -haz-aá & 'sweep' & 92 & 9 \\
\hline b. & -súl-uu & -sul-i & sul-i & sul-úu & -sul-ár & -sul-aá & 'cover up' & 52 & 10 \\
\hline c. & -kélés-ir & -kélés-i & keles-i & keles-úu & -keles-aŕ & -keles-aá & 'rinse' & 48 & 17 \\
\hline d. & -lúlús-uu & -lúlús-i & lulus-i & lulus-úu & -lulus-ar & -lulus-aá & 'pour' & 32 & 18 \\
\hline e. & -par & -páa & paa & pa-v & -par-ar & $-\mathrm{pa}(\mathrm{w})-\mathrm{a}$ & 'dance' & 36 & 13 \\
\hline f. & -yo-u & -yó & yoo & yo-ú & -yow-ar & -yow-á & 'quarrel' & 19 & 14 \\
\hline g. & -dóng & $-\mathrm{do}$ & do & dóm & -dong-ar & -dom-á & ‘walk’ & 31 & 16 \\
\hline h. & -súk-1 & $-s u v$ & suv & suv-v & -suk-ár & -suw-aá & 'load' & 9 & 12 \\
\hline i. & -cék-1 & $-c \varepsilon$ & $c \varepsilon$ & céb-v & -cعk-aŕ & $-c \varepsilon b-a$ & 'cut' & 28 & 15 \\
\hline j. & -cak-1 & -car & car & car-v & -cak-aŕ & -car-á & 'sit' & 12 & 11 \\
\hline k. & -kpér-u & -kpér & kpér & kpé $\gamma-u$ & -kpér-ar & -kpér-a & 'forgive' & 2 & 21 \\
\hline I. & -kát-1r & -kát-1 & kát-1 & kát-vv & -kát-ar & -kát-aa & 'meet' & 111 & 19 \\
\hline $\mathrm{m}$. & -d’́k-vv & -d’́k-1 & dók-1 & dók-vv & -dok-ar & -dók-aa & 'hold' & 52 & 20 \\
\hline n. & -hár & -há & há & há-v & -hár-ar & -ha(w) -á & 'give' & 17 & 5 \\
\hline o. & -lúu-u & $-1 \mathrm{u}$ & lú & lú-u & -lúw-ar & -luw-á & 'take out' & 17 & 6 \\
\hline p. & -túk-v́v & $-t u v$ & tuv & tov-v & -tuk-ár & -tv-áa & 'decrease' & 5 & 4 \\
\hline$q$. & -kpak-ir & -kpar & kpár & kpar-u & -kpak-ár & -kpar-a & 'take' & 10 & 3 \\
\hline r. & -čl-ír & -cél-í & ç्عl-í & cel-úu & -cel-ár & -cel-áa & 'give back' & 70 & 1 \\
\hline s. & -kót-úu & -kót-í & kot-í & kot-úu & -kot-ár & -kot-áa & 'fold' & 28 & 2 \\
\hline
\end{tabular}

\footnotetext{
${ }^{1}$ Roberts (2013) includes four other paradigms for other ten verbs with motion components and complex stems which we exclude here.
} 


\begin{tabular}{|c|c|c|c|c|c|c|c|c|}
\hline t. & -kuud-ú & -kúud-í & kuud-í & kuud-úu & -kuud-ár & -kuud-áa & 'twist' & 7 \\
\hline u. & -wélés-ír & -wéles-í & wélés-i & weles-úu & -weles-ár & -weles-áa & 'listen’ & 31 \\
\hline v. & -cikil-1r & -cíkíl-1 & cikil-1 & c1kíl-vv & -c1kíl-ar & -c1k1l-aa & 'tickle' & 66 \\
\hline w. & -húlút-uu & -húlút-i & húlút-i & hulút-uu & -hulut-ar & -hulút-aa & 'shout (ritual)' & 25 \\
\hline
\end{tabular}

In table 3, we may observe that a high tone is always used for the imperfective present and the aorist. This predictability reflects a simple rule. The important question then is when we can predict low tone. For the building of the remaining forms, we propose that the stem of the imperative is informative. In this we follow Roberts, but we reach different conclusions.

If a verb has a low tone in the stem for the imperative, then it will have low tone in all other forms except when the form of the imperative is monosyllabic, in which case the infinitive will have high tone. When the verb has high tone in the imperative, things become more complex as conditions become more specific. With many options, one commonly resorts to the existence of a default rule that applies elsewhere. The default for a verb with a high tone in the imperative is to also have high tone for all other forms, like in verbs (k-m). In this, it behaves like the default of low tone. Exceptions can be explained by appealing to morphophonological properties of the stem. First, if the segmental stem of the type /CVr-/ or $/ \mathrm{CVW}^{-/}$as in (n-o), then the past has low tone, despite all other forms having high tone. If the imperative has the shape $/(\mathrm{H}-) \mathrm{H}+\mathrm{H} /(+$ indicates the mora of the suffix $-i / \imath)$, then the shape for the infinitive, the imperfective past, and the past will be $/(\mathrm{L}-) \mathrm{L}+\mathrm{H} /$ as in $(\mathrm{r}-\mathrm{u})$. But if the shape is $/ \mathrm{H}-\mathrm{H}+\mathrm{L} /$, for those same forms, the shape will be $/ \mathrm{L}-\mathrm{H}+\mathrm{L} /$ as in $(\mathrm{v}-\mathrm{w})$. Finally, verbs in (p-q) have two segmental stems in alternation (CVV-vs. CVk-), for such verbs with a high tone imperative, the stem for the past tenses always carries low tone.

Having figured out the rules behind the making of forms in the paradigm, we are left with the question about the function of tone in Kabiyè. Our view is that neither low nor high tone in this language is used as an inflectional exponent for any given inflectional category. The lack of function of high tone could be the more problematic if we accepted that it serves to encode imperfective present and the aorist, but in such an analysis, there would still be two issues to deal with: (i) what is the grammatical link between these two tenses so that we could make sense in functional terms of the fact that the same tone encodes both of them; and (ii) why is high tone also found in the stem of many other different cells of different verbs? Like Kabiyè, Tswana is another good example of a system where tone engages in the formal side of inflection.

Tswana is a Bantu language spoken mainly in South Africa. Creissels (2006) shows that verbal inflection in Tswana is complex because each verb can inflect for a large number of morphosyntactic values, including mood (indicative, circumstantial, subjunctive, imperative, etc.), aspect (present, future, perfect, etc.), polarity (positive $v s$. negative), disjunction (conjunct vs. disjunct), as well as non-finite forms such as the infinitive, the relative and the sequential. Like Kabiyè, Tswana has also two tones: low and high. Like the Otomi case in $\S 1.3$, these tones are lexically associated to roots and affixes, but tone assignment is also subject to complex prosodic rules at word level (Creissels et al. 1997). The issue at hand here is what Creissels (2006:10) treats as 'grammatical high tone'. For this we have the verb $t t^{h}$ alv $\chi a$ p- 'understand' which is a toneless stem surfacing as /HLL/ in the form in (4) as a result of a regular spreading of the high tone of the preceding prefix $\mathrm{ka}^{H}$-.

$$
\begin{aligned}
& \mathrm{ba}^{\mathrm{H}}-\mathrm{ka}^{\mathrm{H}}-\mathrm{tq}^{\mathrm{h}} \mathrm{a}^{\mathrm{H}} \mathrm{lu}^{\mathbf{L}} \chi \mathrm{a}^{\mathbf{L}} \mathrm{n}-\mathrm{a}^{\mathrm{L}} \\
& \text { s3-POT-understand-FIN } \\
& \text { 'They can understand.' }
\end{aligned}
$$


In contrast, in (5) the same toneless stem surfaces as /LHH/, and the high tones in it cannot be explained as the result of any prosodic rule.

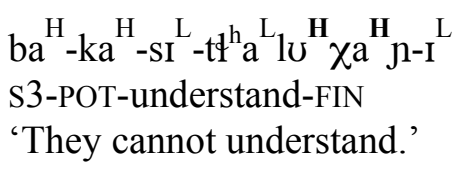

Creissels argues that the distribution of the high tone in (5) is purely morphological as it does not attend to any semantically coherent bundle of morphosyntactic features values. Like the high tone in Kabiyè for the imperfective present and the aorist, the grammatical high tone of Tswana is also found in all negative forms, so in principle, it could be taken to be an exponent of negation alongside other segmental ones (e.g. the prefix $\mathrm{sI}^{\mathrm{L}}-$ ). However it is also found in other forms such as the positive indicative perfect conjunct, the positive circumstantial perfect, the imperative and the sequential. This increase in heterogenic function speaks of lack of morphosyntactic function. What shall we make of the inflectional tones of Kabiyè and Tswana?

The beauty of linguistics is that we can provide different answers to the same questions. Ours here is that tone in both Kabiyè and Tswana plays an important role in the formal making of inflection, but it does not serve any function, that is, tone values cannot be treated as inflectional markers. A similar situation is found in other languages of the book, such as for example in Tibeto-Burman Khaling (Jacques, this volume) and Oto-Manguean Chatino from Zenzontepec (Campbell, this volume). In this section, we have briefly seen well-known ways in which tone can engage in the making of inflection across different types of linguistic systems, in the next section we concentrate on what new lights this book brings to the discussion.

\section{Structure of the book.}

This volume presents a collection of 11 representative articles about the relation between tone and inflectional morphology in different languages. The sample of languages represented covers exemplary linguistic systems in the world where tone is known to have an important role in the inflectional system. Such systems are languages of tonal families spoken mainly in Mexico and in various countries from Africa, but also in Nepal and Papua New Guinea. The authors are specialists on one or more of such languages.

The majority of the papers study some aspect of verbal inflection where tone is involved in some way or another in the inflection of person and aspect, or in a combination of both, although tone is also found involved in the morphology of nouns encoding definiteness (Vydrin, this volume), number (see Crysmann, this volume) or even case beyond the prosodic boundaries of the word (see Hyman, this volume).

This book can help building general knowledge of how tone works in interaction with grammar. We have aimed at this goal by expanding the horizon with novel facts about lesserknown languages of the world, which are either threatened or endangered. This is the reason why the volume includes various papers on Oto-Manguean languages of Mexico because the study of inflection in the families of this large macro-phylum is still at its dawn and all these papers are pioneering.

On the other hand, from a typological perspective the papers in the book cover the most representative types of morphological tone systems cross-linguistically: they include systems where the inflectional role of tone is limited (Papuan, Mian by Fedden) to cases where its role is pervasive across verbal inflection, including cases where tone is mostly associated with 
stem alternations and prosodic patterns (Sino-Tibetan Khaling by Jacques; Amuzgan by Kim; Chatino by Campbell; and Mazatecan by Léonard and Fulcran) to cases where it is better analyzed as an inflectional exponent of the inflected word (from Mixtecan by DiCanio; Palancar, Amith and Castillo García; and Feist and Palancar to Mande by Vydrin).

Some of the contributions show how tonal inflection emerges in languages from the standpoint of diachrony and comparative dialectology, while others show how the complexity of pitch patterns in a given inflectional system from a phonetic perspective can be reduced by means of comprehensive phonological analyses. In general, the study of tone becomes more challenging when the notations of tone as a grammatical formative in most descriptive sources include tonal distinctions which could be alternatively reduced by more comprehensive phonological analyses. Some of the contributions in this volume offer novel comprehensive analyses by revisiting sets of data formerly described as more complex in the sources. Tone patterns have often been analyzed according to a reductionist approach, through complex chunks, instead of a more comprehensive and parsimonious analysis, based on paradigms contrasted by a few allotonic constraints. In this respect, the book also includes two very relevant incursions onto ways in which we can theorize and model the role of tone in inflection. This brings us to the first article in the book.

-In his paper "Morphological tonal assignments in conflict: Who wins?", LARRY HYMAN addresses three very significant issues: (a) what is the inventory of morphological "contributors" to verb tone paradigms? (b) what happens if different contributors conflict? and most relevantly (c) what can we learn from this about how tonal morphology works in general? Hyman shows that tone can do everything that segmental (i.e. non-tonal) morphology can do, and he shows that it can even do much more, because due to its suprasegmental nature it can extend beyond the syntactic phrase blurring the distinction between phonology, morphology, and syntax. The analysis is based on Hyman's vast knowledge of African languages, but it also includes Oto-Manguean by revisiting a previous analysis of Macuiltianguis Zapotec. Because of this paper serves as a perfect theoretical bridge from Africa to the New World.

-BERTHOLD CRYSMANN's contribution is about ways in which we can relate our current descriptive knowledge of how morphological tone works in Hausa to a formal model aimed to produce a solid computational grammar of the language. Crysmann discusses how a separation of segmental and tonal representations akin to the Autosegmental Phonology can greatly facilitate the computational treatment of Hausa, and how it can provide the necessary basis for a grammar-based approach to tone reconstructions. The paper addresses the question of how tonal melodies in Hausa can be best represented so as to generalize over morphological classes independently of the segmental complexity of the base, and Crysmann proposes a novel treatment of tone and length using typed list constraints.

- The article by SEBASTIAN FEDDEN is about the emergence of tone as an inflectional formative in Mian, a Papuan language of the Ok family. Mian is a word-tone language whose lexemes are specified for one out of a set of five tonemes, but tone does little to inflection except for a tiny corner of the grammar that Fedden reveals to us. In Mian, the non-hodiernal past and the imperfective are realized by a homophonous segmental marker. Despite this homophony, many verbs have an aspectual stem distinction that keeps the two grammatical senses apart. For the verbs without the aspectual distinction, a high tone intervenes on the mora of the subject suffix realizing the non-hodiernal past, making the inflected form phonologically distinct from the imperfective. This shows how tone can be recruited for an 
inflectional purpose. Fedden also shows that this high tone is also found in a set of verbs with aspectual stems. While its occurrence in such forms is redundant from a functional point of view, it is an instance of multiple exponence, which is a property typically associated to complex morphology.

- In his paper, GUILLAUME JACQUES studies the nature of the complex stem alternations of the verbal inflection of Khaling, a Sino-Tibetan language of the Kiranti family spoken in Nepal. These alternations involve stems with different tones which occur in paradigms without an apparent functional motivation. In a search for motivation, Jacques goes beyond a solution that appeals to idiosyncrasies of the verbal lexicon, and adopting a diachronic perspective advances a historical account for such tonal alternations showing that the patterns can, at least for the most cases, be explained by two series of sound change. Jacques' contribution is a very illustrative example of how a type of tonal inflection that only attends to morphological structure (i.e. no function and unmotivated) emerges once the conditions that hold the key to the system are lost.

-VALENTIN VYDRIN's article is on two African languages of the Mande group: Bambara (Manding, Western Mande) which is mainly spoken in Mali and the Gwectaa dialect of Dan (Southern Mande, South-Western Mande) spoken in Ivory Coast. The paper is a comparative study of two very different ways in which tone can work as an exponent of grammatical information. Vydrin further suggests a diachronic interpretation for most of the tonal formatives. In Bambara, a 2-level tone system, a floating low tone serves to express definitude on NPs. While Vydrin treats this tone as a definite article which he regards as having an inflectional function. In contrast, the role of tone in the inflection of Dan is much more complex because it has many more functions, including: (i) a replacive extra-low tone on the root of a verb encodes neutral aspect and on nouns serves as an isaphet marker in certain types of inalienable possessive constructions; (ii) a tone lowering of the root of a verb encodes the conjoint dependent status of the verbal construction; (iii) an extra-low tone that manifests itself as a syllable-final tonal modulation is used to produce infinitival forms; (iv) alterations of the tonal contour of adjective stems indicate cumulative plural; and (v) like in the Otomi examples above in $\S 1.3$, many of the pronominal predicative markers (auxiliaries) used for the inflection of verbs in Dan contrast just in tone.

-ERIC CAMPBELL's contribution provides an accurate description of the role of tone in the inflectional morphology of Zenzontepec Chatino, a conservative Chatino language of Mexico from the Zapotecan branch of Oto-Manguean. The tone bearing unit in Zenzontepec Chatino is the mora and morae may bear a high tone, a mid tone, or no tone at all (with a default realization of mid-to-low falling pitch). No-tone morae are detected because they are targets of interesting tonal alterations (also see Vydrin, this volume for a similar system in Bambara). Campbell describes how the encoding of 2 nd person is by means of tone and how tonal allomorphy can be predictable by the stem's phonological shape. In contrast, he also shows tone alterations in the aspect inflection of a subset of the verbal lexicon which undergoes lexically-specified tonal alterations which Campbell claims the best way to account for them is by way of inflectional classes.

-Following with Oto-Manguean languages, JEAN-LÉO LÉONARD and JULIEN FULCRAND's paper is about the internal variation of tonal inflection within the Mazatecan language family of Mexico, another branch of Oto-Manguean spoken in the state of Oaxaca. The authors start by giving the model of the six tone classes in Huautla Mazatec as presented in Pike's seminal 
work (1948). They take this model as base from which they can judge the degree of divergence present in a large sample of primary data collected from modern Mazatecan varieties. At suprasegmental level, the authors propose that Mazatec verb inflection responds to two main processes, downstep affecting mainly the encoding of 1 st person singular; and the obligatory contour principle affecting the expression of other persons (except the 3rd person). Léonard and Fulcrand focus on three representative dialects in their sample and they show in detail how dialectal divergence may occur in a complex system.

-YUNI KIM's article is pioneer in both describing and accounting for the tonal patterns of the Amuzgo language of San Pedro Amuzgos. Amuzgo is another branch of Oto-Manguean and has eight lexical tones where person and number inflection is realized by tone, vowel-height, and glottalization alternations on mostly monosyllabic stems. Kim establishes the relationship between observed tones on inflected forms, and the underlying tonal morphemes that can be considered as the inflectional tones proper. She argues that inflectional tones overwrite lexical tones, demonstrating that tonal inflection patterns cannot be predicted from a lexical item's morphophonological properties, such as its membership to stem-alternation classes, but instead, lexemes must be specified for which tonal inflection pattern they take. But her analysis does not stop there because accounting for inflection-class inventory requires factoring out predictable phonological processes. In this respect, Kim argues that glottally conditioned tone lowering creates surface allotones that are predictable for most cases, meaning that the two most frequent surface patterns in the inflection originate from a single default underlying one. Besides the default many irreducibly distinct classes remain, making Amuzgan inflection typologically challenging.

- Christian DiCANIO's work is a contribution to building general knowledge of tone from the complex system found in Itunyoso Triqui, a Mixtecan, Oto-Manguean language of Mexico with nine lexical tones. Providing both a description and an autosegmental analysis of the morphophonology of person clitics in Triqui, this article is long because of the richness of the primary data. Like in many Oto-Manguean languages, person of subject and possessor is marked in Triqui by enclitics associated to a stem that undergoes tonal adjustments. While the segmental structure of enclitics remains stable in Triqui, there is a complex relation between the stem's morphological/phonological structure and the diverse set of tonal and laryngeal changes which co-occur with cliticization. These are addressed by the author by postulating that certain roots have lexically-specified inflected stem tone allomorphs, while others are organized into two abstract tone classes relating to tone raising.

- In the paper "Tone and verbal inflection in Yoloxóchitl Mixtec", ENRIQUE L. PALANCAR, JoNATHAN D. AMITH and REY CASTILlo GARCÍA study the properties of the tonal inflection of another language of the Mixtecan group, this time of the Mixtec family. Like Trique, Yoloxóchitl Mixtec has a rich tonal inventory with nine contrastive tones at lexical level, but the role of tone in its verbal inflection is very different. From a well-informed sample of 554 verbs collected by Amith and Castillo García as part of a larger documentation project on this endangered language, the authors show that Yoloxóchitl Mixtec is a remarkable language within Oto-Manguean because it uses tone as typical inflectional exponents, i.e. a set of tones are assigned a set of univocal functions. Tonal allomorphy when it exists can be accounted for as being conditioned by the morphophonological properties of the verbal stem. The language does not make use of lexically-specified classes involving tone, but the regularity of tone rules contrasts with the existence of other verb classes involving segmental changes in the stem that need to be listed in the lexicon. 
- In contrast to the system in Yoloxóchitl Mixtec, which is a rather well-behaved tone language for morphosyntactic purposes, TIMOTHY FEIST and ENRIQUE L PALANCAR show that the distribution of tonal inflection in Cuicatec, another key Mixtecan language, is complex to a point that one could be tempted to characterize it as chaotic. However, to disentangle this tonal complexity in a quest for inflectional structure, the authors propose that one way to deal with the Cuicatec system is to focus on the distribution of the first tonal formative of each pattern (or the first tonal element in the case of contour tones). The proposal operates under the hypothesis that this unit is the historical remnant of the tone of an inflectional prefix which a reduced number of verbs still select, and hence the tone carries now its inflectional function. The authors base this pioneer analysis on a sample of 2,480 inflected forms of 620 verbs from the excellent dictionary by Anderson and Roque (1983).

Like any other collective work, this volume is also the fruit of a long string of combined efforts, both personal and institutional. The project for the book started in Paris, at the dawn of the summer of 2013, from a workshop organized by us with a welcoming, bilingual title "Tons et paradigmes flexionnels : modélisation et parcimonie / Disentangling the inflectional role of tone". Since then, we gained more people in the way who did not attend the workshop but were willing to participate in the book. We want to thank the commitment of all authors to this work. Institutionally, the edition of the book has been supported by the ESRC/AHRC project ES/I029621/1 "Endangered Complexity: Inflectional classes in Oto-Manguean languages" as well by the project "Meso-American Morpho-Phonology" by the Institut Universitaire de France.

\section{References cited.}

Aronoff, Mark. 1994. Morphology by itself: Stems and inflectional classes. Cambridge, MA: MIT Press.

Baerman, Matthew and Enrique L. Palancar. Forthcoming. The organization of Chinantec tone paradigms. Cahiers de Grammaire.

Christian T. DiCanio, Jonathan Amith and Rey Castillo García. 2012. Phonetic alignment in Yoloxóchitl Mixtec. Paper read at the 2012 meeting of the Society for the Study of the Indiginenous Languages of America, Portland.

Creisels, Denis, Anderson M. Chebanne, and Heather W. Nkhwa. 1997. Tonal Morphology of the Setswana Verb. München: Lincom Europa.

Creisels, Denis. 2006. Tswana verb morphology and the lexical integrity principle. Lingue e Linguaggio 5:1, 1-18.

Finkel, Raphael and Gregory Stump. 2009. Principal parts and degrees of paradigmatic transparency, in James P. Blevins and Juliette Blevins (eds.), Analogy in Grammar: Form and Acquisition, pp.13-53. Oxford: Oxford University Press.

Foris, David Paul. 2000. A grammar of Sochiapam Chinantec [Studies in Chinantec Languages 6]. Dallas, TX: SIL International and the University of Texas at Arlington.

Hernández-Green, Néstor. In preparation. The inflectional classes of Acazulco Otomi, in Enrique L. Palancar, Matthew Baerman, and Timothy Feist (eds.), Inflectional complexity and verb classes: New lights from the Oto-Manguean languages of Mexico. Oxford University Press.

Merrifield, W. R. and A. E. Anderson. 2007. Diccionario Chinanteco de la diáspora del pueblo antiguo de San Pedro Tlatepuzco, Oaxaca. [2nd Edition] [Serie de vocabularios y 
diccionarios indígenas "Mariano Silva y Aceves" 39]. Mexico DF: Summer Linguistic Institute.

Merrifield, William R. 1968. Palantla Chinantec grammar [Papeles de la Chinantla 5, Serie Científica 9]. Mexico City: Museo Nacional de Antropología.

Pace, W. J. 1990. Comaltepec Chinantec verb inflection, in W. R. Merrifield and C. R. Rensch (eds.), Syllables, tones and verb paradigms [Studies in Chinantec Languages 4], 21-62. Arlington, Texas: The Summer Linguistic Institute and the University of Texas at Arlington

Palancar, Enrique L. In press. Revisiting the complexity of the Chinantecan verb conjugation classes, in Jean-Léo Léonard and Alain Kihm (eds.), Issues in Meso-American morphology. Paris: Michel Houdiard.

Roberts, David. 2013. Conjugaison des verbes en kabiyè (Togo): Tableaux types, règles d'emploi, et index kabiyè-français et français-kabiyè des verbes. Paris: L'Harmattan. 